\title{
Morphological and osteological malformations in hatchery bred redline torpedo fish, Sahyadria denisonii (Day 1865) (Cyprinidae)
}

Sajan Sajeevan ${ }^{1,2} \&$ Thoranam Varkey Anna-Mercy ${ }^{1}$

1 Faculty of Fisheries, School of Fisheries Resource Management and Harvest Technology, Kerala University of Fisheries and Ocean Studies, Panangad, Kochi, Kerala 682 506, India.

2 Doctoral Fellow, School of Bioscience, Mahatma Gandhi University, Kottayam, Kerala 686 560, India.

Correspondence

\section{S. Sajeevan}

E-mail: sajanpolayil@gmail.com

Received: 13 May 2015

Accepted: 18 March 2016

Published on-line: 26 May 2016

\section{Resumen}

Malformaciones morfológicas y oseas en ejemplares de criadero de barbo de línea roja, Sahyadria denisonii (Day 1865) (Cyprinidae)

Se publican, por primera vez, malformaciones morfológicas y osteológicos de Sahyadria denisonii producidas en criadero. Se fotografiaron anomalías morfológicas con cámara digital y de rayos $X$ digital. De 950 larvas producidas, sólo 12 individuos (1,26 \%) presentaron algún tipo de anomalía, incluyendo lordosis, escoliosis, cifosis, semi-opérculo, deformidad de la aleta, deformidad de la boca, deformación de la cabeza y deformidades múltiples. La causa exacta de anomalías no se pudo determinar, pero se discuten las posibles etiologías. Sin embargo, el registro actual es significativo debido a la aparición de deformidades en peces ornamentales de agua dulce de criadero, para los que se considera la reproducción inducida como la clave de su conservación.

Palabras clave: Deformidad, Reproducción inducida, Radiografía, Ghats Occidentales.

\begin{abstract}
This is the first published report on morphological and osteological malformations in hatchery produced Sahyadria denisonii. Morphological abnormalities were photographed with a digital camera and digital X-ray. In present study, out of 950 larvae produced only 12 individuals $(1.26 \%)$ were found to have any type of abnormality, including lordosis, scoliosis, kyphosis, semi-operculum, fin deformity, mouth deformity, head deformity and multiple type deformities. The exact cause of abnormalities could not be definitively determined, but the possible aetiologies are discussed. The present record is, nevertheless, significant owing to the occurrence of deformity in hatchery produced young ones of a freshwater ornamental fish for which induced breeding is considered to be the key to conservation.
\end{abstract}

Key words: Deformity, Induced breeding, Radiography, Western Ghats. 


\section{Introduction}

Deformities in fish are relatively well described with a higher frequency of occurrence reported in hatchery produced individuals than wild (Sennar 1980, Hosoya \& Kawamura 1998, Ma et al. 2014). Deformities in fishes are known to be caused as a result of environmental contaminants, scarcity of nutrients, oxygen deficiency, sudden changes in temperature, water current, mutation, inbreeding, parasitic infestation, mechanic trauma, and attack from predators (Fagbuaro 2009, Amitabh \& Firoz 2010, Tave et al. 2011, Malekpouri et al. 2015). Numerous reports are available regarding abnormalities associated with both freshwater and marine fish species (Poynton 1987, Avyle et al. 1989, Panday \& Awasthi 1994, Madsean \& Dalsgard 1999, Raj et al. 2004, OlatunjiAkioye et al. 2010, Dutta et al. 2011, Jaward \& Mamry 2012, Ma et al. 2014, Sajan et al. 2014, Malekpouri et al. 2015). Sahyadria denisonii (Day 1865), is popularly known as Redline torpedo fish or Miss Kerala and is endemic to the fourteen rivers flowing through the Western Ghats of India (Mercy et al. 2013a, Sajan 2015). This species is much sought after in the international ornamental fish trade (Raghavan et al. 2007, Mercy et al. 2010, Mercy et al. 2015) and it contributes the major share of India's ornamental fish exports during 2005-2012 (Raghavan et al. 2013). As a result of targeted and indiscriminate exploitation of this species for aquarium trade from wild listed those into endangered group. To the best of our knowledge, occurrence of any kind of deformities in hatchery produced $S$. denisonii has not yet been reported. This paper documents for the first time different types of deformities recorded in hatchery produced $S$. denisonii.

\section{Material and methods}

\section{Induced breeding and larval rearing}

Ripe $S$. denisonii were anaesthetised to minimise handling stress (Sajan et al. 2012) and induced bred at fish hatchery of College of Fisheries, Kerala, India (Mercy et al. 2015). The newly hatched larvae (Average size $=3.50 \pm 0.20 \mathrm{~mm}$ ) consume its yolk up to 4 days of post hatch, and then paramecium culture was given as the first exogenous feed. After a week of larval husbandry, they were weaned with live micro worms (Panagrellus re- divivus (Goodey, 1945)) and followed by Artemia Flakes (OSI feeds, U.S.A) and commercial formulated diet (Higahsi Aqua feeds Pvt. Ltd) with crude protein $(38 \%)$, crude fat $(4 \%)$, crude fibre (3\%), ash (16\%) and moisture (11\%). The formulated feed was given twice a day ad libitum throughout the study period, the unconsumed feeds and excrements were siphoned out from the tanks and $1 / 3$ portion of the water in each tanks was exchanged before next feeding (Mercy \& Sajan 2014). Water quality parameters such as temperature, dissolved oxygen, $\mathrm{pH}$, alkalinity, hardness and ammonia were daily monitored by following standard procedures (APHA 1992) and maintained within optimum ranges.

\section{Examination of deformities}

950 hatchery bred larvae were examined and abnormal specimens were anaesthetized by using MS-222 (Mercy et al. 2013b). Morphological abnormalities were photographed with a digital camera (Nikon Coolpix L22) and it was further examined with digital X-ray system (Fujifilm FCR Capsula XL II Reader). Morphological, anatomical terminologies relating to the fish abnormality were used by following Al-Harbi (2001). We selected all the deformed fish that could be observed in that particular breeding batch. For the comparison of abnormality, a normal specimen was also radiographed. The deformed specimens were preserved in $4 \%$ formaldehyde solution and deposited in the Museum of Department of Fishery Biology, College of Fisheries, KUFOS, Panangad, Kerala, India (FRM-SAH-DEN/2013-2).

\section{Results}

In present study, out of 950 larvae produced only 12 individuals $(1.26 \%)$ were found to have any type of abnormality. These abnormal fishes were grown up to an average length of $5.60 \pm 0.84 \mathrm{~cm}$ in the hatchery compared to normal specimen $(6.40 \pm 0.53 \mathrm{~cm})$, before they were sampled for the study (4-6 month of age). Length and weight of deformed specimens except those affected semi-operculum were measured. The water quality parameters were recorded as temperature (27.0 $\left.\pm 0.50{ }^{\circ} \mathrm{C}\right), \mathrm{pH}(7.0 \pm 0.3)$, dissolved oxygen $(5.29$ $\pm 0.24 \mathrm{ppm})$, alkalinity ( $35.6 \pm 6.0 \mathrm{ppm})$, hardness $(55.46 \pm 10.28 \mathrm{ppm})$ and ammonia $(<0.02 \mathrm{ppm})$. Different types of morphological as well as osteo- 
logical malformations recorded in $S$. denisonii were listed in Table. 1. In present study, malformations were externally apparent compared to normal specimens (Figs. 1, 2) and observed deformities include semi-operculum, vertebral deformity, head deformity, mouth deformity, fin deformity and also multiple deformities.

\begin{tabular}{lc} 
Type of deformity & Occurrence (\%) \\
\hline Lordosis & 12.9 \\
Scoliosis & 9.68 \\
Kyphosis & 3.23 \\
Semi-operculum & 6.45 \\
Fin deformity & 22.6 \\
Mouth deformity & 9.68 \\
Head deformity & 9.68 \\
Multiple deformity & 25.8 \\
\hline
\end{tabular}

Tabla 1. Porcentaje de ocurrencia de diferentes tipos de deformidad en S. denisonii.

Table 1. Percentage of occurrence of different types of deformity in S. denisonii.

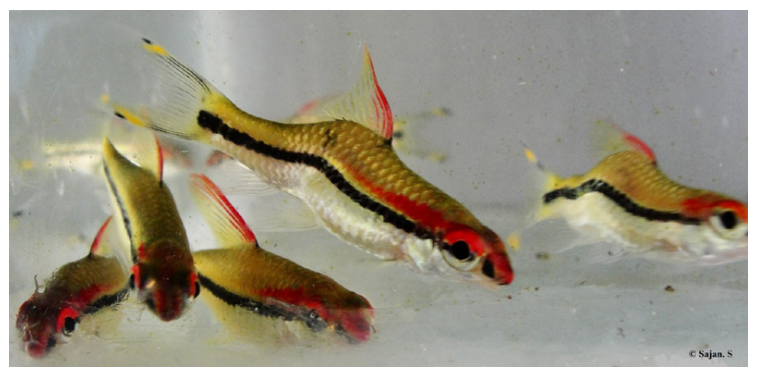

Figura 1. Ejemplares de criadero de $S$. denisonii con anomalías Figure. 1. Hatchery produced $S$. denisonii with abnormalities.

Vertebral malformations were recorded by the presence of excessive inward curvature and abnormal lateral curvature respectively (Fig. 3). Scoliosis was affected the vertebral column at the post dorsal fin region of $S$. denisonii (Fig. 4) had total length of $5.8 \mathrm{~cm}$ (Body weight of $2.16 \mathrm{~g}$.) compared to normal fish had total length of 6.2 $\mathrm{cm}$ (Body weight of $2.15 \mathrm{~g}$ ). In the present study, vertebral deformities were frequently affected in the posterior half of the spinal column (Figs. 3c, 3d). Meanwhile one abnormal fish was noticed with lordosis and kyphosis (Fig. 3c). Abnormal fishes had functional double chambered swimbladder (Figs. 3c, 3d), similar to normal specimen (Fig. 2b).

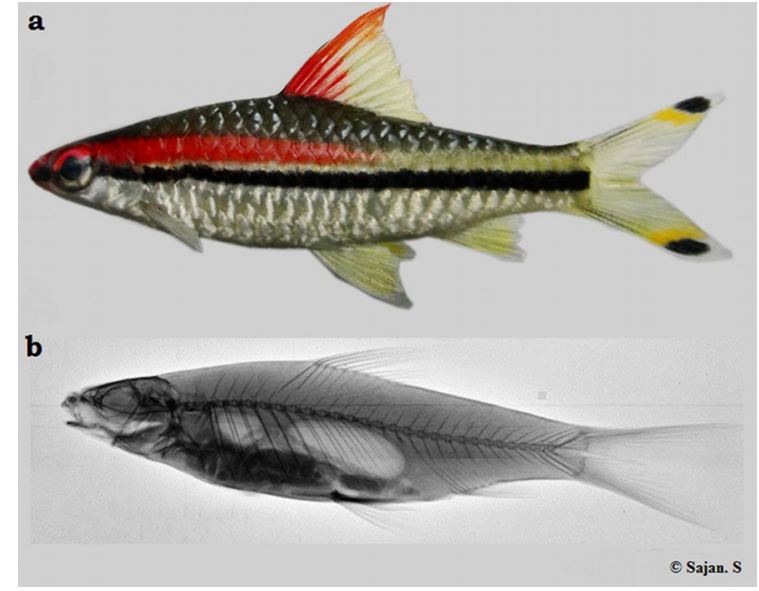

Figura 2. a: Espécimen normal de $S$. denisonii. anomalías. b: Radiografía.

Figure 2. a: Normal specimen of $S$. denisonii. b: X-ray image.

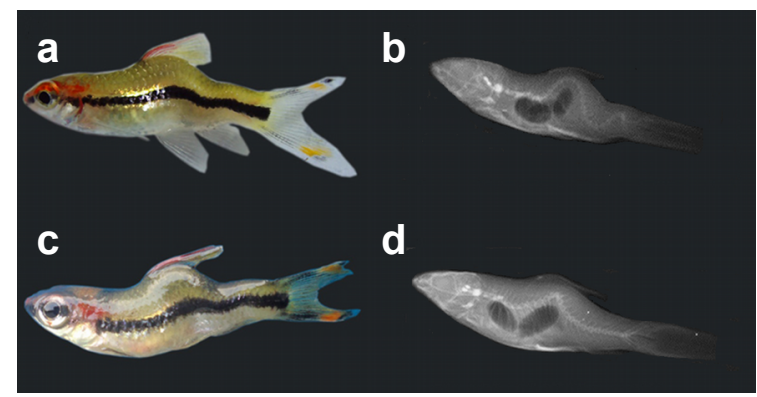

Figura 3. a, b: Ejemplares de $S$. denisonii con lordosis. c-d: Radiografías mostrando lordosis y cifosis.

Figure 3: a, b: $S$. denisonii showing lordosis. c-d: X-ray image showing lordosis and kyphosis.

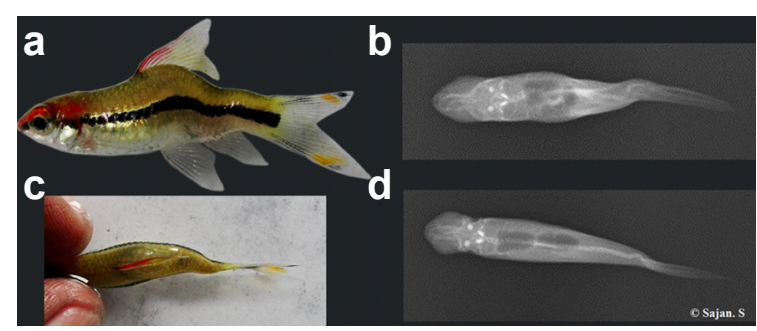

Figura 4. a, b: Ejemplares de $S$. denisonii mostrando escoliosis. c, d: Radiografías mostrando escoliosis.

Figure 4. a, b: $S$. denisonii showing scoliosis. c, d: X-ray image showing scoliosis.

Normal specimen of $S$. denisonii has mouth at sub-terminal position (Figs. 2a, 2b), while malformed specimens had depressed lower and upper jaw (Fig. 5b). Head of deformed specimen appeared as laterally compressed and shortened (Fig. 5a) compared to normal specimen (Figs. 2a, $2 b)$. Type of head deformities like beak-head, inward bending of the lower jaw and shortening of the neurocranium were also noticed in $S$. den- 


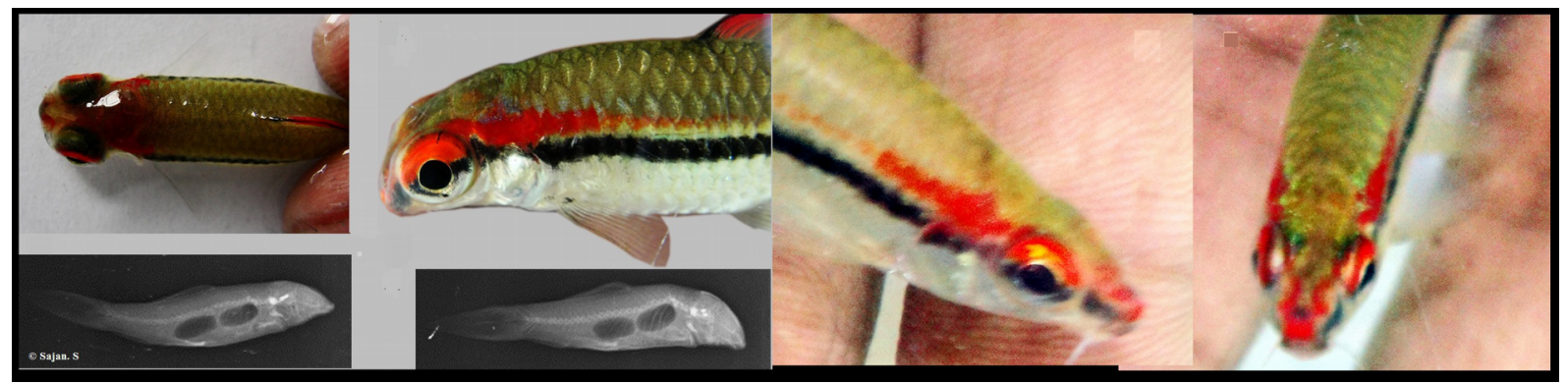

Figura 5. a: $S$. denisonii mostrando deformidad en cabeza. b: Deformidad en boca. c, d: Radiografías mostrando deformidades en boca y cabeza. e, f: Vista dorsal de espécimen normal.

Figure 5. a: S. denisonii showing head deformity. b: Showing mouth deformity. c, d: X-ray image showing mouth and head deformity. e,f: Dorsal view of normal specimen.

isonii (Figs. 5c, 5d). A case of unilateral semioperculum was observed in $S$. denisonii by the shortening of the posterior part of operculum (Figs. 6a, 6b). Fin abnormalities were mainly affect the dorsal-caudal fins (Fig. 7a) and abnormal caudal fin observed as truncated towards the posterior side (Figs. 7a, 7b). More than one deformities (Multiple deformity) were recorded in eight abnormal specimens like semi-operculum, spinal deformity, head deformity, mouth deformity or fin deformity in one sample itself (Figs. 1, $6 b)$.

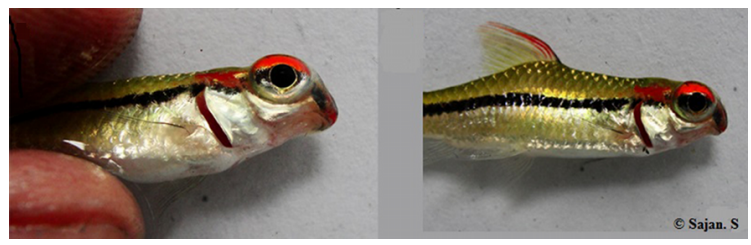

Figura 6. a,b: $S$. denisonii mostrando deformidad de semiopérculo.

Figure 6. a,b: $S$. denisonii showing operculum deformity

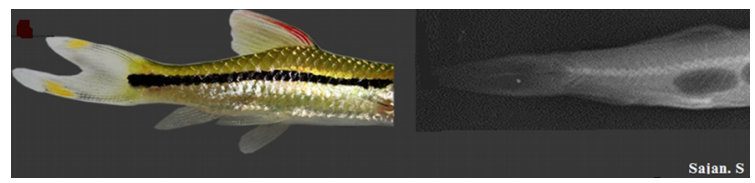

Figura 7. a: S. denisonii mostrando deformidad en aletas caudal y dorsal. b: Radiografía mostrando deformidad en aletas caudal y dorsal.

Figure 7. a: S.denisonii showing caudal and dorsal fin deformity b: X-ray image showing caudal and dorsal fin deformity.

\section{Discussion}

Information's on body malformation is an important biological aspect in hatchery production of fish larvae. Larvae of several freshwater fish pro- duced through induced breeding exhibit morphological abnormalities that adversely affect their survival rate (Daoulas et al. 1991, Gavaia et al. 2002, Sahoo et al. 2004, Sahoo et al. 2007, Boglione et al. 2013). Available evidence suggests that abnormalities are induced during the embryonic and post-embryonic periods of life (Al-Harbi 2001). In present study, we describes different abnormalities have been recorded in hatchery produced S. denisonii.

Occurrence of vertebral deformities are more common in early stages as compared to adults, which may be attributed to that deformed fish at early stages were more prone to mortality (Amitabh \& Firoz 2010). Vertebral deformities like lordosis and scoliosis was recorded in S. denisonii by the presence of excessive inward curvature and abnormal lateral curvature respectively. According to Boglione et al. (1993), scoliosis is the lateral bending of the vertebral axis, it is the most easily distinguishable abnormality in live fishes. $S$. denisonii with scoliosis had two curvatures in the vertebral column at the post dorsal region, one below the dorsal fin region and second at the caudal peduncle region. In present study, vertebral deformities were more affected generally at the posterior half of the vertebral column. Similar types of vertebral deformities were reported in Fundulus heteroclitus (L., 1766) (Gabriel 1944) and Esox lucius L., 1758 (Orska 1962). Recently, wild caught specimen of $S$. denisonii from River Valapattanam, Kerala was also recorded with vertebral deformity (Sajan et al. 2014).

Spinal deformities were found to be associated with the absence of a functional swim-bladder (Iseda et al. 1979, Kitajima et al. 1981, Daoulas et al. 1991, Chatain 1994, Andrades et al. 1996). In the present study, deformed fish had normal 
double chambered swim-bladder similar to Cyprinus carpio L., 1758 (Al-Harbi 2001) and Labeo rohita (Hamilton, 1822) (Dutta et al. 2013). Fluctuation in water temperature is considered to be one of the causes of the spinal deformities, because by the sudden change in water temperature may lead to abnormal muscle growth and spinal deformity (Al-Hassan 1982, Wang \& Tsai 2000, Davidson et al. 2011). Low dissolved oxygen content in the water during spawning and developmental stages may also responsible for vertebral deformity (Al-Hassan 1982). But in the present study, dissolved oxygen content may never a limiting factor, because continuous aeration was provided in the hatching and rearing tanks to maintain dissolved oxygen level. The water quality parameters were maintained at optimum level, so in present study it is unable to correlate deformities with water quality parameters.

In present study, average length and weight of ten abnormal fish have been found to be substantially lower than that of normal fishes, probably due to their inability to feed normally and compete with the normal ones for food (Al-Harbi 2001). Dabrowski et al. (1988) and Frischkenecht et al. (1994) reported vitamin-C deficiency in the diet also leads to vertebral deformities. Finally, a genetic basis has also been proposed for spinal deformations (Fagbuaro 2009, Arbuatti et al. 2013), vertebral deformities are known to be hereditary and non- hereditary (Yamamoto et al. 1963). Vertebral abnormalities are also known to occur in Cirrhinus mrigala (Hamilton, 1822) and Hypothalmichthys motitrix (Valenciennes, 1844) (Raj et al. 2004) and Poecilia wingei Poeser, Kempkes \& Isbrücker, 2005 (Arbuatti et al. 2013) due to inbreeding depression. In present study deformed fishes were not analysed genetically, hence it could not be ascertained whether the anomalies were hereditary or non-hereditable. Mouth abnormalities of various types have been reported in Dicentrarchus labrax (L., 1792) (Barahona-Fernades 1982) and C. carpio (AlHarbi 2001). The mouth position of normal specimen of $S$. denisonii is sub-terminal, but the deformed specimens had depression on their lower and upper jaw of the mouth. Jaw deformity is known to be caused by many factors such as mechanical injury, nutritional deficiency, environmental condition, parasitism or genetic aberration (Quigley 1995). Beak like appearance of head, inward bending of the lower jaw and shortening of the neurocranium were also noticed in malformed S. denisonii. According to Al-Harabi (2001) distended or compressed head of deformed fishes may be due to the ossification or compression of bones.

Operculum related malformations are attributed to inside or outside folding, shortening or abnormal positioning of the opercular and subopercular bones, bilaterally or unilaterally (Boglione et al. 1993, Galeotti et al. 2000). In present study, unilateral semi-operculum malformation was observed in $S$. denisonii. Commonly abnormality is seen only on one side of the operculum (unilateral), while some species had bilateral semi-operculum (Al-Harbi 2001). Operculum deformity has also been reported in hatchery raised Oreochromis niloticus (L., 1758) (Mair 1992), Oreochromis mossambicus (Peters, 1852) (Handwerker \& Tave 1994). Vitamin-C deficiency related operculum deformity has been reported in Oncorhynchus mykiss (Walbaum, 1792) (Frischknecht et al. 1994) and C. carpio (Dabrowski et al. 1988). Fishes with such deformity can swim normally, but their growth was less than that of compared to the normal fish (Al-Harbi 2001).

Dorsal and caudal fin abnormalities were recorded in deformed specimen of $S$. denisonii. Similar types of fin disorders have also been observed in Pampus argenteus (Euphrasén, 1788) (Mamry et al. 2010), C. mrigala (Dutta et al. 2011) and Moolgarda pedaraki (Valenciennes, 1836) (Jaward \& Mamry 2012). According to Boglione et al. (1993), fin anomalies are frequently observed in hatchery reared fish, but their frequency and severity vary according to the species, rearing condition or types of rearing tank. Some of the deformed specimen of S. denisonii had multiple deformities, such as semi-operculum, spinal deformity, head deformity, mouth deformity and fin deformity in one fish, similar reports by Tave et al. (1982) in Oreochromis aureus (Steindachner, 1864) (=Sarotherodon aureus (Steindachner, 1864)), Dabrowski et al. (1988) in C. carpio, Wiegand et al. (1989) in Carassius auratus L., 1758 and Frischknecht et al. (1994) in O. mykiss.

Fish deformities have been also resulted from nutritional deficiencies, unfavourable abiotic factors, rearing conditions and genetic factors (Yamamoto et al. 1963, Tave et al. 1982, Dab- 
rowski et al. 1988, Boglione et al. 1993, Frischknecht et al. 1994, Wang \& Tsai 2000, Fagbuaro 2009, Amitabh \& Firoz 2010, Arbuatti et al. 2013). However, earlier studies reported that the possible aetiologies and mechanisms responsible are not well understood (Koumoundouros et al. 1997, Gavaia et al. 2002). This study has attempted to provide insights into the morphological and osteological deformities in hatchery produced young ones of $S$. denisonii. We could not observe any deformed fish that died before we commenced our investigation. However, we are not sure whether we had overlooked any while in the larval stage. This is not a problem in the hatchery since we got good survival rate. This is reported as a case report as it is the first of its kind. S. denisonii is a difficult to breed fish and the captive breeding technology of the species has been developed first by the authors (Mercy et al. 2015).

The present study does not mean to discuss the causes of the abnormalities, but only to single out the fact that such deformities are recorded in the hatchery-reared $S$. denisonii. Even though the exact cause of deformity was not determined in the present study, unfavourable abiotic conditions, inappropriate nutrition, genetic defects, disruption of early developmental process or a combination of these factors could all have been involved in the malformations in S. denisonii. Therefore, more research is needed to exactly identify the factors causing such deformities. However, the present record is nevertheless significant owing to the occurrence of deformity in hatchery produced young ones of a highly sought after freshwater ornamental fish for which captive breeding is considered to be the key to conservation and sustainable use.

\section{Acknowledgements}

Authors thank the authority, College of Fisheries, Kerala University of Fisheries and Ocean Studies, Ernakulam, India for providing the necessary facilities to carry out this work. Sajan. S, thanks the Government of Kerala for the doctoral research fellowship (Mahatma Gandhi University, Kottayam) during 2010-2013. The authors thank the MPEDA for Project on "stock assessment and development of captive breeding technology of Sahyadria denisonii, an endemic indigenous ornamental fish of Western Ghats of India (2007-
2010)".

\section{References}

Al-Harbi AH. 2001. Skeletal deformities in cultured common carp Cyprinus carpio L. Asian Fisheries Science 14: 247-254.

Al-Hassan LAJ. 1982. Vertebral deformities in fishes from Iraq and the United Arab Emirates, Arabian, Gulf. Iraqi Journal of Marine Science 1: 13-23.

Amitabh H \& Firoz AM. 2010. A wild specimen of Indian Carp, Cirrhinus mrigala (Hamilton, 1822) with multiple Vertebral Deformities. World Journal of Zoology 5: 167-177.

Andrades JA, Becerra J \& Fernandez-Llebrez P. 1996. Skeletal deformities in larval, Juvenile and adult stages of cultured gilthead sea beam (Sparus aurata L). Aquaculture 141: 1-11.

APHA 1992. Standard methods for the examination of water and wastewater. 18th edition. American Publication and Health Association, Washington, D.C, USA, p.1288.

Arbuatti A, Salda LD \& Romanucci M. 2013. Spinal deformities in a wild line of Poecilia wingei bred in captivity: report of cases and review of the literature. Asian Pacific Journal of Tropical Biomedicine 3(3): 186-190.

Avyle VDMJ, Carvick SJ, Blazer VS, Hamilton SJ \& Brumbaugh WG. 1989. Skeletal deformities in Small Mouth Bass, Micropterus dolomieni from southern Appalachian Reservoirs. Archives of Environmental Contamination and Toxicology 18: 688-696.

Barahona-Fernades MH. 1982. Body deformities in hatchery reared European sea bass (Dicentrarchus labrax L). Types, prevalence, and effect on fish survival. Journal of Fish Biology 21: 239-249.

Boglione C, Marino G, Bertolini B, Rossi A, Ferreri F \& Cataudella S. 1993. Larval and postlarval monitoring in sea bass: morphological approach to evaluate finfish seed quality. In: Barnabe $G$ \& Kestemont P. (Eds), Proceedings on Environment and Quality. Bordeaux Aquaculture '92, Gent, Belgium. European Aquaculture Society Special Publication vol. 18 pp. 189-204.

Boglione C, Gisbert E, Gavaia P, Witten PE, Moren M, Fontagn S \& Koumoundouros G. 2013. Skeletal anomalies in reared European fish larvae and juveniles. Part 2: main typologies, occurrences and causative factors. Reviews in Aquaculture 5: 121-167.

Chatain B. 1994.Abnormal swim bladder development and lordosis in Sea bass (Dicentrarchus labrax L) and sea bream (Sparus auratus). Aquaculture 97: 169-180.

Dabrowski K, Hinterleither S, Sturmbauer C, El-Fiky N \& Wieser W. 1988. Do carp larvae require vitamin C?. Aquaculture 72: 295-306.

Daoulas CH, Economou AN \& Bantavas I. 1991. Osteological abnormalities in laboratory reared sea-bass (Dicentrarchus labrax) fingerlings. Aquaculture 97: 169-180.

Davidson. J, Good C, Welsh C \& Summerfelt ST. 2011. 
Abnormal swimming behaviour and increased deformities in rainbow trout Oncorhynchus mykiss cultured in low exchange water recirculating aquaculture systems. Aquaculture Engineering 45: 109-117.

Dutta SPS, Slathia D, Chander G \& Kumar H. 2011. Anomalies in Cirhhinus mrigala, a commercially important fresh water food fish, from Gurdaspur district of Punjab. The Bio Scan 6: 405-411.

Dutta SPS, Slathia D \& Katoch V. 2013. Morphological and Skeletal Deformities in Labeo rohita (Ham. Buch.). International Journal of Fisheries and Aquaculture Sciences 3(1): 45-62.

Endo M \& Iwatsuki Y. 1998. Anomalies of wild fishes in water of Miyazaki. Southern Japanese Bulletin of Faculty of Agriculture 45: 27-35.

Fagbuaro O. 2009. Inbreeding of mouth malformed and crocked back Clarias gariepinus. Journal of Agriculture Science and Technology 3(12): 44-50.

Fagbuaro O, Awopetu JI, Oso JA. 2006. Common deformities in hatchery bred Clarias gariepinus and its hybrids in Nigeria. Journal of Applied Environmental Science 2:177-181.

Frischknecht R, Wahli T, Meier W. 1994. Comparison of pathological changes due to deficiency of vitamin C, vitamin $E$ and combinations of vitamin $C$ and $E$ in rainbow trout, Oncorhynchus mykiss (Walbaum). Journal of Fish Diseases 17:31-45.

Gabriel ML. 1944. Factors affecting the number and form of vertebrae in Fundulus heteroclitus. Experimental Zoology 95: 105-147.

Galeotti M, Beraldo P, de Dominis P, D'Angelo L, Ballestrazzi R \& Musetti R. 2000. A preliminary histological and ultrastructural study of opercular anomalies in gilthead sea bream larvae (Sparus aurata). Fish Physiology and Biochemistry 22: 151-157

Gavaia PJ, Dinis MT \& Cancela ML 2002. Osteological development and abnormalities of the vertebral column and caudal skeleton in larval and juvenile stages of hatchery-reared Senegal sole (Solea senegalensis). Aquaculture 211: 305-323.

Handwerker TS \& Tave D. 1994. Semioperculum: A nonheritable deformity in Mozambique Tilapia. Journal of Aquaculture and Animal Heath 6: 85-88.

Hosoya K \& Kawamura K. 1998. Skeletal formation and abnormalities in the caudal complex of the Japanese flounder, Paralichthys olivaceus (Temminck and Schlegel). Bulletin of National Research Institute of Fisheries Science 12: 97-110.

Iseda $\mathrm{H}$, Ishihara $\mathrm{M}$, Sumida $\mathrm{S}$, Owaki M \& Tabata S. 1979. Prevention of deformation in the juveniles of red sea bream, Pagrus major reared in ponds. Relationship between the initial rearing conditions and the lordotic deformity. Bulletin of Kumamoto Prefectural Fisheries Experimental Station 1: 9-17.

Jaward LA \& Mamry JSA. 2012. Caudal fin deformity in long finned mullet, Moolgarda pedaraki (Valencieences 1836) (Pisces: Mugillidae). Croatian Journal of Fisheries 70: 65-69.

Kitajima C, Sukashima Y, Fujita S, Watanabe T \& Yone Y. 1981. Relationship between uninflated swimbladders and lordotic deformity in hatchery reared red sea bream Pagrus major. Bulletin of Japanese Soci- ety for Scientific Fisheries 47: 1289-1294.

Koumoundouros G, Gagliardi F, Divanach P, Boglione C, Cataudella S \& Kentouri M. 1997. Normal and abnormal osteological development of caudal fin in Sparus aurata L. fry. Aquaculture 149: 215-226.

Ma Z, Tan DAY \& Qin JG. 2014. Jaw deformities in the larvae of yellowtail king fish (Serioloa lalandi Valenciennes, 1833) from two groups of brood stock. Indian Journal of Fisheries 61(4): 137-140.

Madsean L \& Dalsgard I. 1999. Vertebral column deformities in farmed rainbow trout on Oncorhynchus mykiss. Aquaculture 171: 41-48.

Mair GC. 1992. Caudal deformity syndrome (CDS): an autosomal recessive lethal mutation in the tilapia, Oreochromis niloticus (L.). Journal of Fish Diseases 15: 71-75.

Malekpouri P, Mesbah M \& Rezaie A. 2015. Aetiology of skeletal deformity in a Barbus grypus (Heckel, 1843) fish: clinical and radiological studies. Comparative Clinical pathology 24: 201-206.

Mamry JMA, Jawad LA, Rasady IHA \& Habsi SHA. 2010. First record of dorsal and anal fin deformities in silvepomfrets, Pampus argenteus (Stromateidae, Actinopterygii). Anales de Biologica 32: 73-77.

Mercy TVA, Sajan S \& Malika V. 2015. Captive breeding technology and developmental biology of Sahyadria denisonii (Cyprinidae) an endangered fish of the Western Ghats of India. Indian Journal of Fisheries 62(2): 19-28.

Mercy TVA \& Sajan S. 2014. Early Growth Performance of an endangered barb Sahyadria denisonii (Day 1865) Fed with Different Diets under Controlled Conditions. Fishery Technology 51: 286-290.

Mercy TVA, Malika V \& Sajan S. 2013a. Reproductive biology of Puntius denisonii (Day 1865)- an endemic ornamental cyprinid of the Western Ghats of India. Indian Journal of Fisheries 60: 73-78.

Mercy TVA, Malika V \& Sajan S. 2013b. Use of tricaine methanesulfonate (MS-222) to induce anaesthesia in Puntius denisonii (Day, 1865) (Teleostei: Cypriniformes: Cyprinidae), a threatened barb of the Western Ghats, India. Journal of Threatened Taxa 5: 4414-4419.

Mercy TVA, Malika V \& Sajan S. 2010. Breakthrough in Breeding of Puntius denisonii. Info Fish International 3: 14-17.

Olatunji-Akioye AO, Adeyemo OK \& Akomolafr OT. 2010. Photographic and radiograpic study of osteological abnormalities of the head of adult African catfish (Clarias gariepinus). International Journal of Morphology 28:719-722.

Orska J. 1962. Anomalies in the vertebral columns of the Pike Esox lucicus. Acta Biologica Craco Series for Zoology 5:327-345.

Panday KD \& Awasthi S. 1994. Threatened Fishes of India. In: Dehadari PV, Das P \& Verma SR. (Eds.). Nature Conservators, Muzaffarnagar, India. p.480.

Poynton SL. 1987. Vertebral column abnormalities in Brown Trout Salmo trutta. Journal of Fish Diseases 10: 53-57.

Quigley DTG. 1995. A lower Jaw deformity in juvenile 
and adult Atlantic salmon (Salmo salar L). Bulletin of European Association for Fish Pathology 15: 206209.

Raghavan R, Tlusty M, Prasad G, Pereira B, Ali A \& Sujarittanonta L. 2007. Should endemic and threatened freshwater fishes of Kerala part of the Western Ghats biodiversity hotspot be captive bred for international trade?. Current Science 99: 1211-1213.

Raghavan R, Dahanukar N, Tlusty MF, Rhyne AL, Krishna Kumar K, Molur S \& Rosser AM. 2013. Uncovering an obscure trade: Threatened freshwater fishes and the aquarium pet markets. Biological Conservation 164: 158-169.

Raj AJA, Seetharaman S \& Haniffa MA. 2004. Skeletal deformities in few freshwater fishes from Bhavani River, Tamil Nadu. Zoos print Journal 19: 16281629.

Sahoo SK, Giri SS, Chandran S \& Sahu AK. 2007. Effect of ovaprim doses and latency periods on induced spawning of Clarias batrachus: Observation on larval deformity. International Journal of Experimental Biology 45: 920-922.

Sahoo SK, Giri SS, Swain T \& Sahu TK. 2004. Observations on some common abnormalities in induced bred Clarius batrachus hatchlings. Journal of Inland Fish Society of India 36: 67-71.

Sajan S, Malika V \& Mercy TVA. 2012. Use of an ecofriendly anaesthetic in the handling of Puntius denisonii (Day, 1865)- an endemic ornamental barb of the Western Ghats of India. Indian Journal of Fisheries 59: 131-135.

Sajan S, Mercy TVA \& Malika V. 2014. Record of a wild specimen of Redline torpedo fish, Puntius denisonii (Actinopterygii: Cyprinidae) with vertebral deformity. Anales de Biologica 36: 33-35.

Sajan S. 2015. Studies on the stock dynamics and reproductive biology of Sahyadria denisonii (Day 1865)- an endangered ornamental fish of the Western Ghats of India. Ph.D. Thesis. Mahatma Gandhi University, Kottayam, Kerala, India. p. 340.

Sennar IW. 1980. An evolutionary ecological perspective. In: Soule, M.E. and B.A. Wilcox (Eds.). Conservation Biology. California University Press, California. p.161.

Tave D, Bartels JE \& Smitherman RO. 1982. Stumpbody Sarotherodon aureus (Steindachner) (Tilapia aurea) and tail-less S. niloticus (L.)(T. nilotica): two vertebral anomalies and their effects on body length. Journal of Fish Diseases 5: 487-494.

Tave D, Jo JY \& Kim DS. 2011. Gross Abnormalities in Tilapia. Fisheries and Aquatic Science 14: 148-160.

Wang LH \& Tsai CL. 2000. Effects of temperature on the deformity and sex differentiation of Tilapia, Oreochromis mossambicus. Journal of Experimental Zoology 286: 534-537.

Wiegand MD, Hataley JM, Kitchen CL \& Buchanan LG. 1989. Induction of developmental abnormalities in larval goldfish. Carassius auratus $L$ under cool incubation conditions. Journal of Fish Biology 35: 8595.

Yamamoto T, Yomita H \& Matsuda N. 1963. Hereditary and Non-heritable vertebral anchylosis in Medaka, Oryzias latipes. International Journal of Genetics 38: 36-47. 